\title{
Downward particulate organic carbon export at high temporal resolution in the eastern Fram Strait: influence of Atlantic Water on flux composition
}

\author{
Catherine Lalande*, Eduard Bauerfeind, Eva-Maria Nöthig \\ Alfred Wegener Institute for Polar and Marine Research, 27570 Bremerhaven, Germany
}

\begin{abstract}
A sediment trap was deployed at $340 \mathrm{~m}$ from April to July 2003 to monitor the downward export of particulate organic carbon (POC) at high temporal resolution in the marginal ice zone of the eastern Fram Strait. Although POC fluxes remained $<15 \mathrm{mg} \mathrm{m}^{-2} \mathrm{~d}^{-1}$, variations in the magnitude and composition of the exported POC were observed during deployment. A first period of elevated POC export associated with an increase in diatom fluxes and low zooplankton fecal pellet fluxes was recorded at the beginning of May, suggesting a mismatch between phytoplankton production and zooplankton grazing. A second period of elevated POC export composed of coccolithophores, diatom resting spores and empty diatom frustules was observed in June. This transition in the composition of the export fluxes reflected a shift in water masses caused by the onset of an ice-edge eddy bringing warm Atlantic Water into the region at the beginning of June. The cyclonic eddy also contributed to the rapid export of Phaeocystis pouchetii, a microalga that does not significantly contribute to carbon export in stratified waters. The main contributors to the zooplankton fecal pellet flux also varied according to the prevailing water mass, with copepod fecal pellets dominating throughout the deployment, except at the beginning of June, when the fecal pellet flux in Atlantic Water was dominated by appendicularian fecal pellets. These results indicate that a prevalence of Atlantic Water may have a large impact on the magnitude and composition of POC export in the eastern Fram Strait.
\end{abstract}

KEY WORDS: POC export - Sediment trap $\cdot$ Fecal pellets $\cdot$ Eddy $\cdot$ Atlantic Water $\cdot$ Fram Strait

\section{INTRODUCTION}

Because of the highly episodic nature of primary production in seasonally ice-covered areas, the export of organic carbon to the deep ocean, or its retention in the upper water, is determined by the interaction between the development of the phytoplankton community and the seasonal dynamics of zooplankton (Andreassen et al. 1996, Wassmann et al. 1996, 2004, Sakshaug 2004, Lalande et al. 2007). A match or mismatch between phytoplankton blooms and zooplankton grazing has important consequences for the ecosystem as it affects the magnitude and composition of the exported particulate matter and hence the food supply to benthic communities (Grebmeier \& Barry 1991, Klages et al. 2004). The magnitude and composition of the exported material is particularly important in the deep Fram Strait, where food availability at the seafloor is the determinant factor controlling large-scale distribution patterns of deep-sea megafauna (Soltwedel et al. 2009).

The Fram Strait, located between Northeast Greenland and the Svalbard Archipelago, is a gateway for Atlantic Water entering the Arctic Ocean. The warm Atlantic Water $\left(3\right.$ to $\left.4^{\circ} \mathrm{C}\right)$ transits northward with the West Spitsbergen Current in the eastern Fram Strait, where it merges with the cold Arctic Water $\left(<0^{\circ} \mathrm{C}\right)$ flowing southward with the East Greenland Current 
in the western Fram Strait (Schauer et al. 2004, Polyakov et al. 2005). Sea ice conditions and the position of the ice edge in the Fram Strait are mainly determined by the interactions between the warm Atlantic Water and the cold Arctic Water, with permanent ice-covered areas in the west, permanent icefree areas in the southeast, and seasonally varying conditions in the central and eastern Fram Strait (Blachowiak-Samolyk et al. 2007). Therefore, seasonal and interannual variations in water mass distribution and sea ice cover are major factors constraining the timing and magnitude of primary production in the Fram Strait when sunlight is sufficient.

Several investigations using short-term drifting or long-term moored sediment traps have been conducted in the seasonally ice-covered Arctic Ocean to estimate the magnitude and seasonal variability of particulate organic carbon (POC) export (e.g. Wassmann et al. 2004). However, fluxes were usually obtained for brief deployments $(\sim 24 \mathrm{~h})$ or for long deployments with low temporal resolution, whereby each flux measurement corresponds to several days or weeks. In the present study, a sediment trap was deployed at high temporal resolution in the marginal ice zone of the eastern Fram Strait to better evaluate the temporal variability of POC export in relation with the development of the phytoplankton and zooplankton communities. This sediment trap was deployed as part of a time series of sedi-

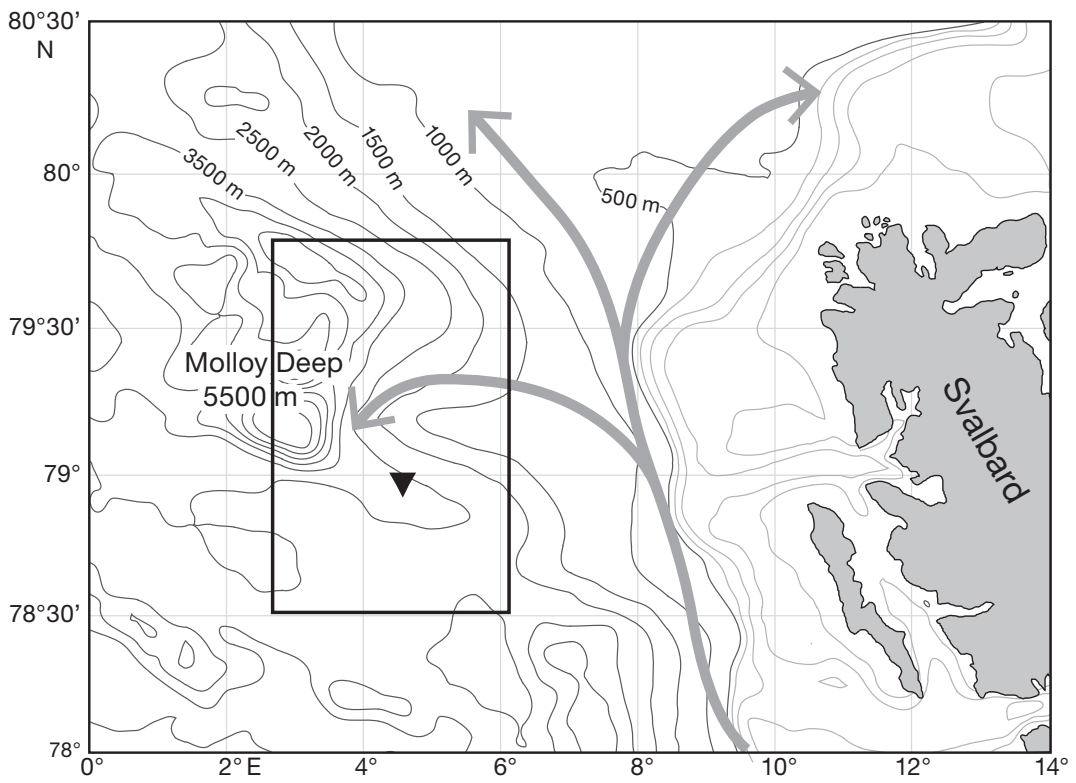

Fig. 1. Location of the sediment trap (black triangle) deployed from April to July 2003 at the HAUSGARTEN observatory (black rectangle) in the eastern Fram Strait west of the Svalbard Archipelago. The gray arrows represent branches of the West Spitsbergen Current carrying Atlantic Water into the region ment trap deployments performed since 2000 at HAUSGARTEN, an observatory established by the Alfred Wegener Institute for Polar and Marine Research to detect and track the impact of largescale environmental changes in the transition zone between the northern North Atlantic and the central Arctic Ocean (Bauerfeind et al. 2009). This high resolution investigation of the magnitude and composition of the sinking material provides insight on the processes affecting the downward POC export in this remote region.

\section{MATERIALS AND METHODS}

\section{Sampling}

A modified automatic Kiel sediment trap with a sampling area of $0.5 \mathrm{~m}^{2}$ and 20 collection cups (Kremling et al. 1996) was deployed at $340 \mathrm{~m}$ for $80 \mathrm{~d}$ from 25 April to 14 July 2003 at the HAUSGARTEN observatory, located $\sim 120 \mathrm{~km}$ west of Spitsbergen in the eastern Fram Strait (78 59' N, $4^{\circ} 27^{\prime}$ E; water depth = 2568 m; Fig. 1). Sediment trap sampling cups rotated every $4 \mathrm{~d}$ to measure downward export fluxes at high temporal resolution. Sample cups were filled with filtered seawater poisoned with $\mathrm{HgCl}_{2}(0.14 \%$ final solution) and adjusted to a salinity of 40 with $\mathrm{NaCl}$, to preserve samples during deployment and after recovery. In the laboratory, swimmers were removed with forceps and rinsed under a dissecting microscope before splitting of subsamples for the measurement of $\mathrm{POC}$, calcium carbonate $\left(\mathrm{CaCO}_{3}\right)$, biogenic particulate silica (bPSi), phytoplankton cells, and zooplankton fecal pellets. Preparations and measurements of the subsamples were performed as described by von Bodungen et al. (1991), with the exception of acidification of $\mathrm{CaCO}_{3}$ and POC filters, which were soaked with $0.1 \mathrm{~N} \mathrm{HCl}$ instead of fuming with concentrated $\mathrm{HCl}$. Filters for $\mathrm{CaCO}_{3}$ measurements were weighed before acidification, rinsed with distilled water to remove residual $\mathrm{CaCl}_{2}$ after treatment, and reweighed after drying at $60^{\circ} \mathrm{C} . \mathrm{CaCO}_{3}$ values were calculated from the weight difference to total mass, while POC measurements were conducted on a Carlo Erba CHN analyzer. POC fluxes were not cor- 
rected for dissolution of organic material in the sampling cups and should be considered as minimum values. Subsamples for bPSi were filtered on polycarbonate filters (pore size: $0.8 \mu \mathrm{m}$ ), and bPSi measurements were obtained by wet-alkaline digestion of the samples (von Bodungen et al. 1991).

Additional subsamples were used for the microscopic analysis of phytoplankton cells and zooplankton fecal pellets. Phytoplankton cells were enumerated by inverted microscopy according to the Utermöhl (1958) method. A minimum of 50 to 100 phytoplankton cells of the dominant groups were counted at 4 magnifications $(100,160,250$, and $400 \times$ ) using phase contrast microscopy. Only the dominant and identifiable cells were counted, including intact cells, empty frustules, and resting spores of diatoms. Zooplankton fecal pellets were enumerated (50 to 700 pellets depending on the subsample) using a dissecting scope. The length and width of each fecal pellet were measured at 2 magnifications ( 20 or $25 \times$ ), and pellet volumes were calculated based on the cylindrical or ellipsoidal shape of the pellets. According to their shape and size, cylindrical pellets were attributed to calanoid copepods and ellipsoidal pellets with a diameter $>60 \mu \mathrm{m}$ were attributed to appendicularians (Sampei et al. 2009). Ellipsoidal pellets with a diameter $<60 \mu \mathrm{m}$ may be attributed to the small cyclopoid copepod Oithona similis (Sampei et al. 2009), but no pellets corresponding to this size were measured. Fecal pellet volumes were converted to fecal pellet carbon (FPC) using a volumetric carbon conversion factor of $0.057 \mathrm{mg} \mathrm{C} \mathrm{mm}^{-3}$ for copepod pellets and $0.042 \mathrm{mg}$ C $\mathrm{mm}^{-3}$ for appendicularian pellets (González \& Smetacek 1994, González et al. 1994). POC, $\mathrm{CaCO}_{3}$, bPSi, phytoplankton cells, and zooplankton FPC fluxes were averaged to daily fluxes for each collection period.

\section{Remote sensing}

Daily sea ice concentrations in the sampling region were obtained by analysis of satellite-derived Advanced Microwave Scanning Radiometer for EOS (AMSR-E) data provided by the National Snow and Ice Data Centre. The $89 \mathrm{GHz}$ AMSR-E sensor and the ARTIST Sea Ice (ASI) algorithm were used, yielding a spatial resolution of $6.25 \times 6.25 \mathrm{~km}$ (Spreen et al. 2008). Satellite-derived chlorophyll a concentrations (chl a) above the sediment trap were obtained from 7 April to 15 July 2003 from the GlobColour Project (ESA). Chl a concentrations were retrieved at a reso- lution of $4 \mathrm{~km}$ and for $8 \mathrm{~d}$ binning periods using the semi-analytical GSM algorithm (Garver \& Siegel 1997, Maritorena et al. 2002) applied to merged water leaving reflectance spectra from SeaWiFS, MODIS and MERIS datasets (Maritorena \& Siegel 2005). GSM was selected over usual empirical algorithms to minimize the impact of optical constituents (colored detrital material and non-algal particles). Although the GSM algorithm has not been validated for the Arctic Ocean, the semi-empirically derived chl a concentration patterns are more realistic than the ones obtained using empirical algorithms (Bélanger et al. 2008).

\section{RESULTS}

\section{Ice and chl a concentrations}

Ice concentration in the sampling region was $20 \%$ during the first weeks of deployment, increased to $\sim 40 \%$ at the beginning of June, and remained at this concentration for the rest of the deployment period (Fig. 2a). Chl a concentrations were $>1 \mathrm{mg} \mathrm{m}^{-3}$ at the start of the deployment and ranged between 0.5 and $1.5 \mathrm{mg} \mathrm{m}^{-3}$ for most of the deployment period (Fig. 2b). The highest chl a concentration was observed in May, while the lowest chl a concentration was measured in June (Fig. 2b).

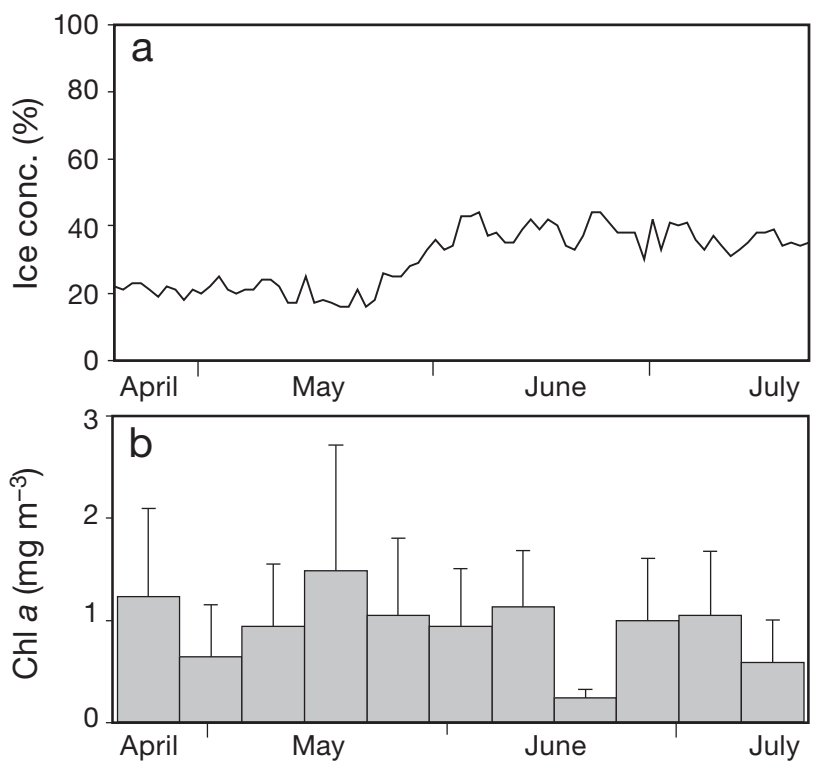

Fig. 2. Temporal variations in satellite-derived (a) sea ice concentration averaged over the sampling region (78.5 to $79.5^{\circ} \mathrm{N}, 2.5$ to $6.5^{\circ} \mathrm{E}$ ) and (b) chl a concentration averaged over the sampling region ( 78 to $80^{\circ} \mathrm{N}, 2$ to $7^{\circ} \mathrm{E}$ ) in the eastern Fram Strait in 2003. The bars represent standard deviations 


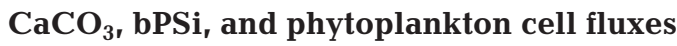

$\mathrm{CaCO}_{3}$ fluxes were high at the end of April, decreased during the month of May, and increased again at the beginning of June, while bPSi fluxes were elevated at the beginning of May and low in June and July (Fig. 3). Concurring with the elevated bPSi fluxes, an enhanced export of diatoms was observed at the beginning of May (Fig. 4). Pennate diatoms, mainly the chain-forming Fragilariopsis cylinders and F. oceanica, and centric diatoms of the genus Thalassiosira spp. reached their highest flux values in the first week of May, while empty diatom frustules and resting spores of Chaetoceros spp. mostly contributed to the phytoplankton flux in June. Elevated fluxes of Phaeocystis pouchetii were observed at the beginning of June, while increased coccolithophore fluxes (mainly of Emiliania huxleyi and a few Coccolithus pelagicus) were observed during most of the month of June. Fluxes of large identifiable phytoplankton cells decreased to low values during the month of July (Fig. 4).

\section{POC and FPC fluxes}

POC fluxes were $<15 \mathrm{mg} \mathrm{C} \mathrm{m}^{-2} \mathrm{~d}^{-1}$ during the complete deployment (Fig. 5a). Periods of increased POC export were observed at the beginning of May $(12 \mathrm{~d}$ $\left.>5 \mathrm{mg} \mathrm{C} \mathrm{m}^{-2} \mathrm{~d}^{-1}\right)$ and at the end of June $(16 \mathrm{~d}>10 \mathrm{mg}$ $\mathrm{C} \mathrm{m}^{-2} \mathrm{~d}^{-1}$ ). FPC fluxes remained $<5 \mathrm{mg} \mathrm{C} \mathrm{m}^{-2} \mathrm{~d}^{-1}$ during the deployment, were highest at the end of May and in June, and decreased considerably in July
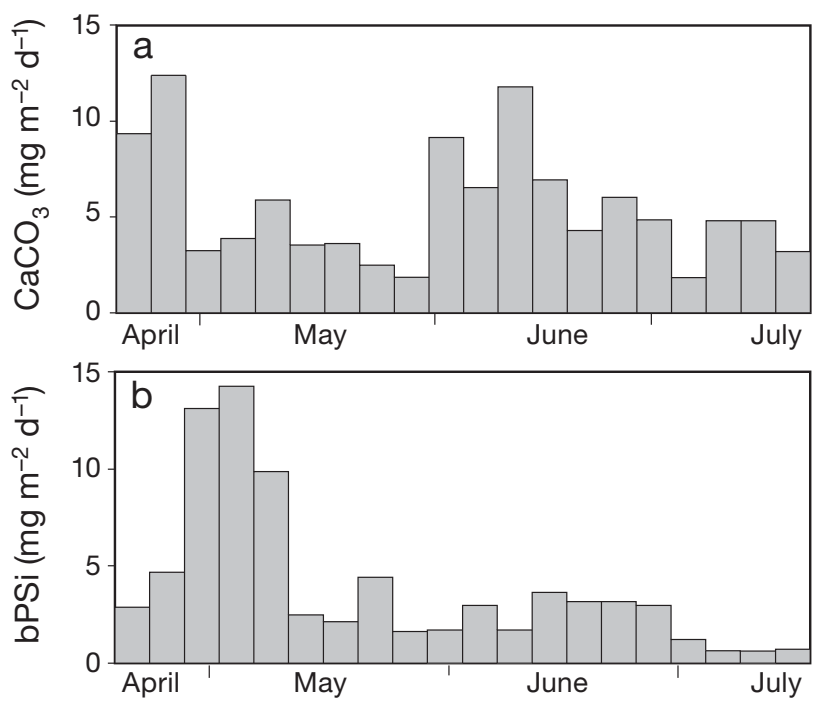

Fig. 3. Temporal variations in (a) calcium carbonate $\left(\mathrm{CaCO}_{3}\right)$ fluxes and (b) biogenic particulate silica (bPSi) fluxes measured at $340 \mathrm{~m}$ in the eastern Fram Strait in 2003
(Fig. 5a). The contribution of FPC to the POC flux ranged between 10 and $30 \%$ at the beginning of the deployment, substantially increased to supply $>85 \%$ of the POC flux at the end of May, and remained between 40 and $70 \%$ until mid-June when the contribution of FPC to the POC flux decreased to an average of $10 \%$ for the rest of the deployment (Fig. 5b). Copepod fecal pellets were present in all samples and dominated the FPC fluxes, except during a short
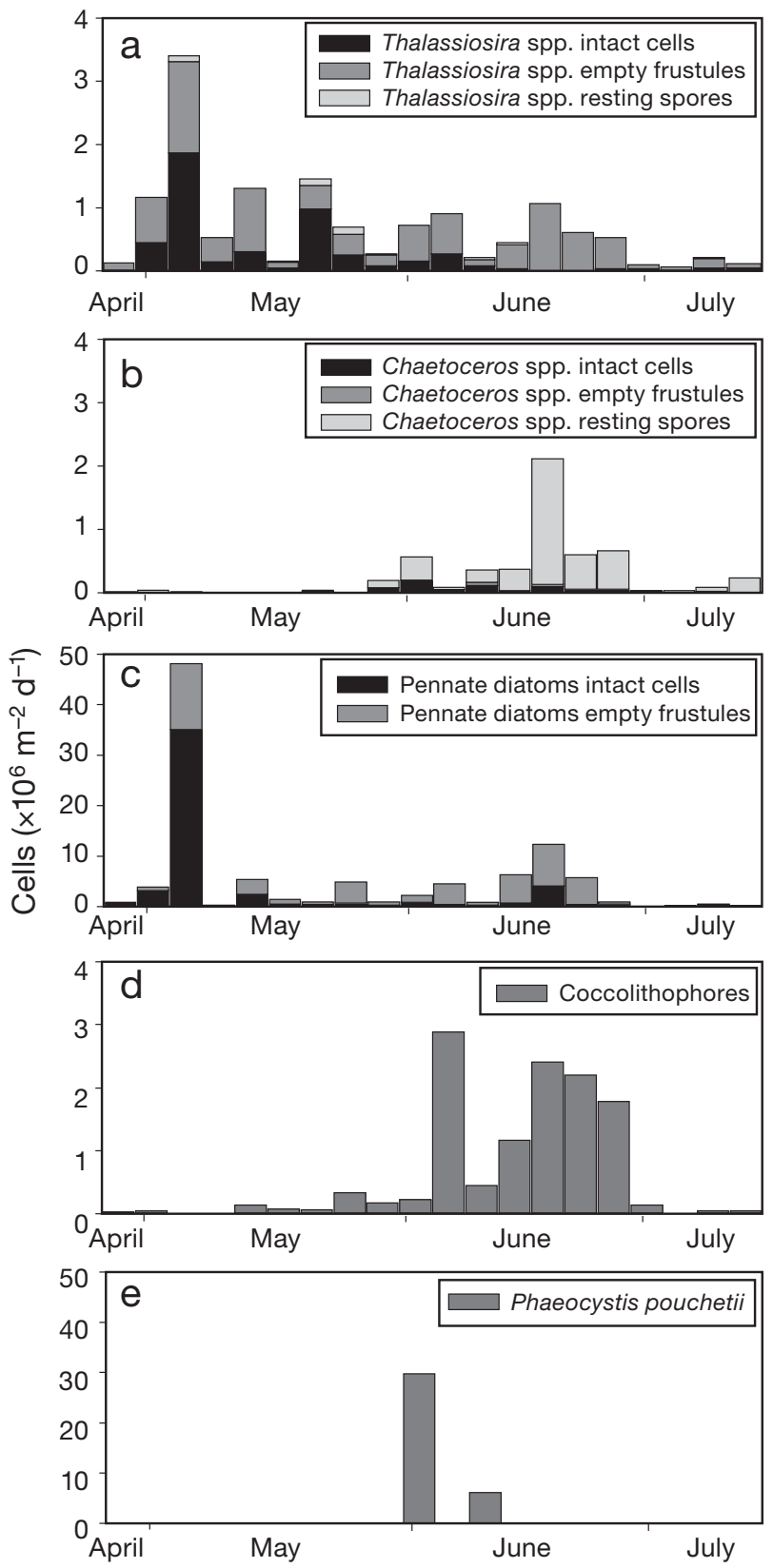

Fig. 4. Temporal variations in cell fluxes of (a) Thalassiosira spp., (b) Chaetoceros spp., (c) pennate diatoms, (d) coccolithophores, and (e) Phaeocystis pouchetii measured at $340 \mathrm{~m}$ in the eastern Fram Strait in 2003. Note the different scales 


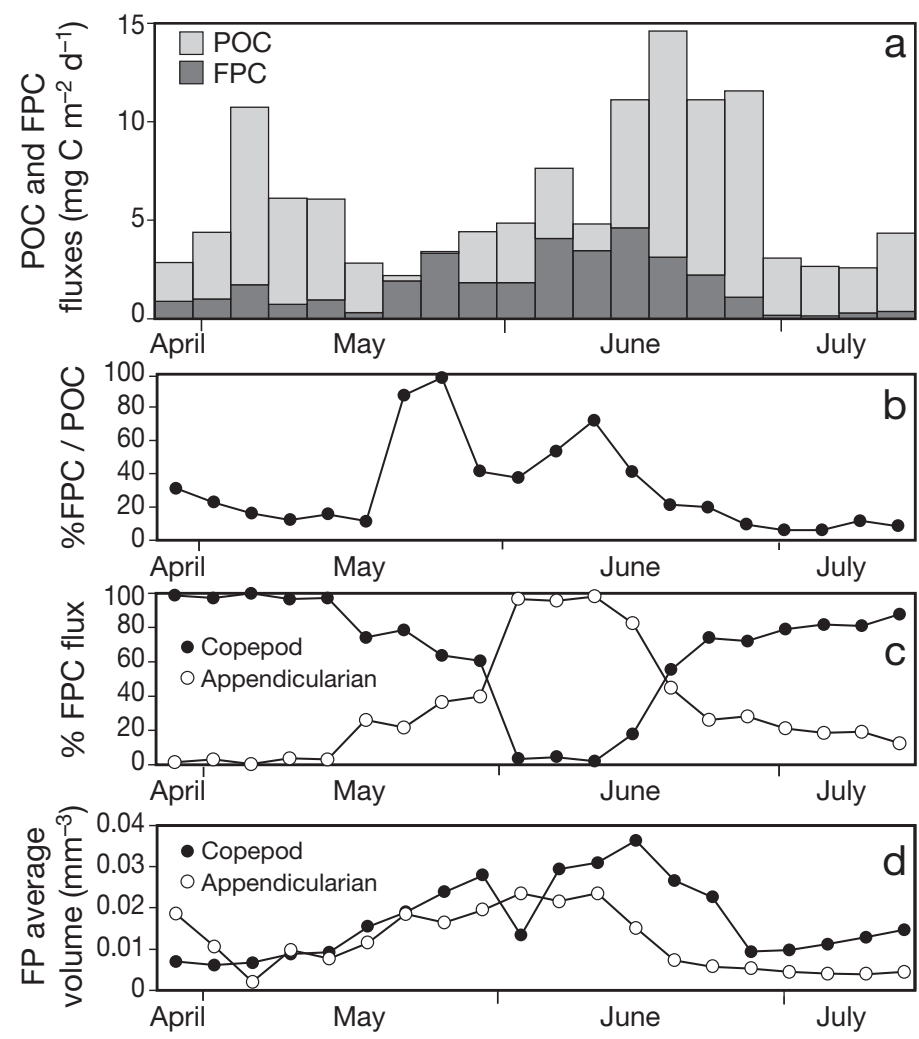

Fig. 5. Temporal variations in (a) particulate organic carbon (POC) and fecal pellet carbon (FPC) flux, (b) contribution of FPC to the POC flux, (c) contribution of copepod and appendicularian FPC, and (d) average copepod and appendicularian fecal pellet (FP) volume measured at $340 \mathrm{~m}$ in the eastern Fram Strait in 2003

period at the beginning of June when they were nearly absent from the samples (Fig. 5c). Appendicularian fecal pellets completely dominated the FPC fluxes at the beginning of June but were nearly absent at the start of the deployment (Fig. 5c). Copepod and appendicularian fecal pellet volumes steadily increased with time until a rapid decline in June (Fig. 5d). The low copepod fecal pellet volume recorded at the beginning of June resulted from the small fragments of broken fecal pellets collected in the sample (Fig. 5d).

\section{DISCUSSION}

An unusual increase in ice concentration in the sampling region, instead of the expected decrease in ice cover due to melting at the beginning of June, indicated the formation of an ice-edge eddy, a common feature along the ice edge in the Fram Strait (Wadhams \& Squire 1983, Johannessen et al. 1987a,b). Indeed, ice concentration maps revealed the presence of a cyclonic eddy transporting ice over a large area directly above the sediment trap from 2 June to 2 July (Fig. 6). With typical scales of from 30 to $40 \mathrm{~km}$ and a lifetime of at least 20 to $30 \mathrm{~d}$, mesoscale eddies have a large impact on ice distribution in the Fram Strait (Johannessen et al. 1987a,b, Shuchman et al. 1987). In addition to dragging ice away from the main ice pack, cyclonic eddies transport warm Atlantic Water beneath the ice (Wadhams \& Squire 1983, Johannessen et al. 1987b). Therefore, the coincident deployment of the sediment trap with the occurrence of an ice-edge eddy provided a unique opportunity to assess the influence of the advection of warm Atlantic Water on POC export in the eastern Fram Strait.

\section{POC export prior to the ice-edge eddy}

The enhanced diatom and diatom-specific bPSi fluxes at the beginning of May suggest that the deployment of the sediment trap coincided with the onset of a bloom. Although satellite-derived measurements have limited viewing conditions and were partially hindered by ice cover, the chl a concentration recorded at the end of April was above the threshold value of $1.0 \mathrm{mg} \mathrm{m}^{-3}$ defining a bloom (Wu et al. 2007), supporting an enhanced primary production at the time of the deployment. A phytoplankton bloom occurs when nutrient-rich water is exposed to light during ice break-up and water from the melting ice gives rise to strongly stratified surface water (Peinert et al. 2001, Fortier et al. 2002, Sakshaug 2004, Lalande et al. 2007). The influence of ice on primary production was reflected by the export of ice-associated pennate diatoms Fragilariopsis spp. known to be quantitatively important during the spring bloom in the Arctic Ocean (von Quillfeldt 2000). A large export of pennate diatoms recorded from the end of April to the beginning of May 2003 by another longterm sediment trap deployed at the HAUSGARTEN observatory emphasizes the importance of the spring bloom for POC export in the region (Bauerfeind et al. 2009). The elevated $\mathrm{CaCO}_{3}$ fluxes observed prior to the increase in diatom-specific bPSi fluxes at the start of the deployment may reflect the release of foraminifera from melting sea ice. High benthic foraminifera fluxes due to sea-ice rafting were observed from January to May in the eastern Fram Strait (Hebbeln 2000); however, the low abundance of foraminifera collected in the sediment trap was not sufficient to explain the elevated $\mathrm{CaCO}_{3}$ fluxes observed during the first days of deployment in our study, and these high $\mathrm{CaCO}_{3}$ fluxes remain unexplained. 


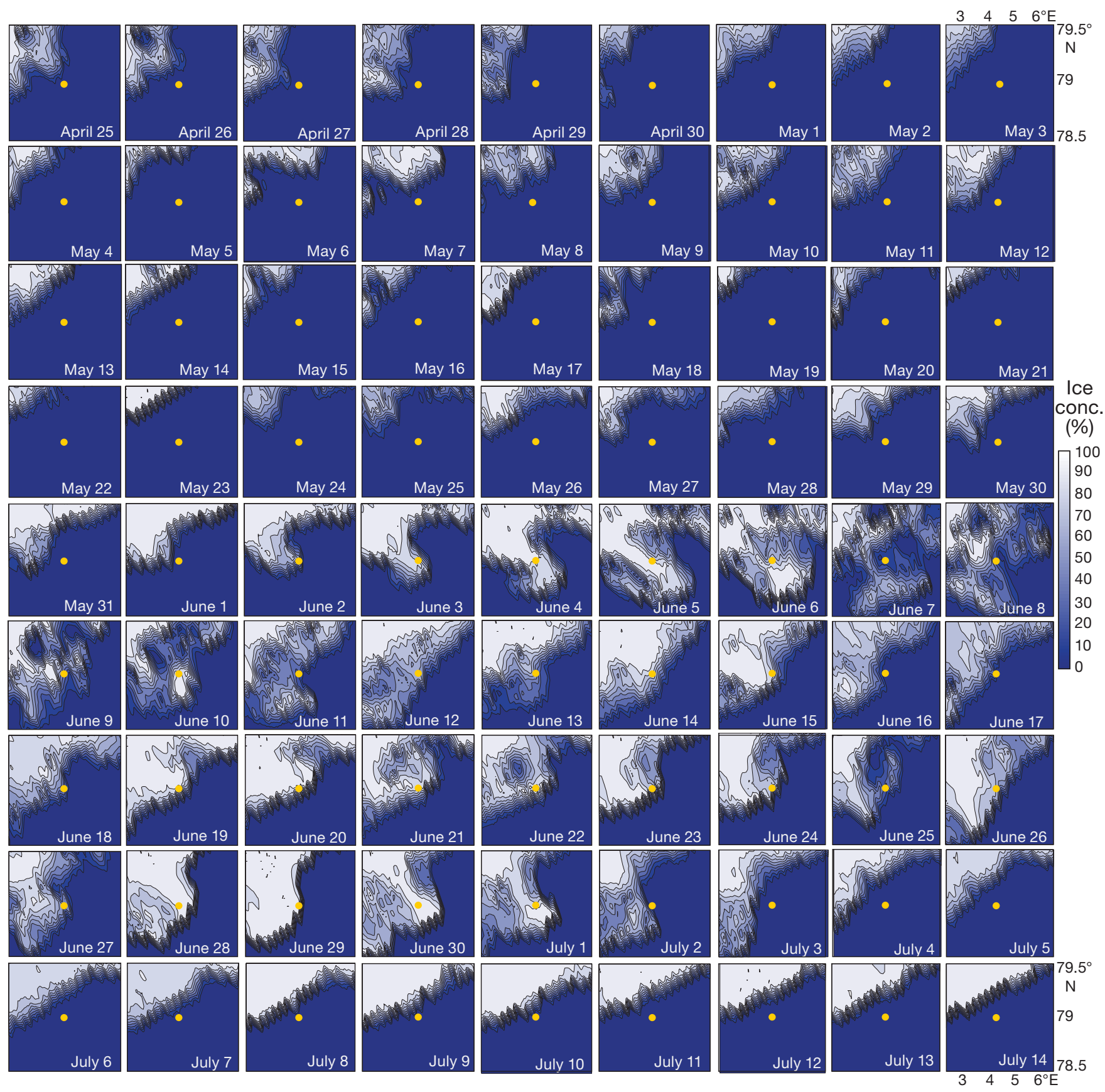

Fig. 6. Ice concentration maps for the complete deployment period showing the presence of an ice-edge eddy above the sediment trap from 2 June to 2 July 2003. The location of the sediment trap is indicated by a yellow dot

Because zooplankton fecal pellets sink rapidly (Turner 2002), the absence of a coincident increase in zooplankton fecal pellet fluxes with the increase in diatom fluxes at the beginning of May suggests that fecal pellets were retained in the upper water column or were not abundantly produced. However, the enhanced export of diatoms implies a lack of retention, and low fecal pellet fluxes likely reflect low zooplankton biomass and fecal pellet production at the start of the deployment. In fact, the proportion of fecal pellets in the POC flux remained low until it abruptly increased above $85 \%$ at the end of May due to a considerable increase in fecal pellet fluxes, suggesting that zooplankton biomass was low during the first weeks of deployment and rapidly increased in May. This large increase in fecal pellet fluxes may reflect the advection of zooplankton in the region, but most likely reflects the seasonal ontogenetic mi- 
gration of copepods. Hirche (1997) reported a southnorth gradient in the timing of the ascent of the population of the copepod Calanus hyperboreus from the Norwegian Sea to the central Arctic Ocean, with the ascent beginning in March in the Norwegian Sea, in April in the Greenland Sea, and in June in the central Arctic Ocean. Given the location of the Fram Strait between the Greenland Sea and the central Arctic Ocean, it is probable that the overwintering copepods surfaced in May in the region.

The plausible mismatch between zooplankton grazing and the phytoplankton bloom before the return of the overwintering copepods resulted in an increased export of intact phytoplankton cells and POC at the beginning of May. Previous investigations in the Arctic Ocean have also shown that a rapid increase in food supply and low zooplankton biomass during the spring bloom may cause a large export of ungrazed phytoplankton cells (Olli et al. 2002, Wassmann et al. 2004, Lalande et al. 2007). This mismatch period is commonly followed by a period of reduced POC export and elevated fecal pellet fluxes due to the extensive grazing pressure resulting from higher abundances of large copepods and sufficient feeding conditions. The increase in the contribution of fecal pellets to the POC flux at the end of May, with fecal pellets comprising nearly the entire POC flux, reflects this expected match between phytoplankton and zooplankton. In the eastern Fram Strait, zooplankton abundance and biomass is dominated by calanoid copepods (Hop et al. 2006), as reflected by a majority of copepod fecal pellets exported at that time. This large contribution of copepod fecal pellets to the POC flux is comparable to the export of fecal pellets from the copepod Calanus finmarchicus, which accounted for $92 \%$ of the total carbon export at the end of a spring bloom in May in the Norwegian Sea (Graf 1989).

Despite the low amount of diatoms collected in the sediment trap following the elevated diatom and diatom-specific bPSi fluxes measured in the first weeks of May, another increase in bPSi fluxes was observed at the end of May. The almost complete contribution of fecal pellets to the POC flux at that time suggests that the bPSi was exported through fecal pellets. Thus, fecal pellets enhanced the export of bPSi in the eastern Fram Strait, similar to previous observations made at a nearby station off northern Spitsbergen, where fecal pellets were the most prominent source of sinking particulate silicate (Andreassen et al. 1996), and in the Antarctic Polar Front region, where fecal pellets contributed significantly to biogenic silica and POC fluxes during spring (Dagg et al. 2003).

\section{Influence of Atlantic Water on POC export}

The advection of warm Atlantic Water due to the formation of an ice-edge eddy at the beginning of June directly in the collection area of the sediment trap rapidly modified the composition of the POC flux. The first effect associated with the onset of the eddy was the large collection of the haptophyte Phaeocystis pouchetii in the sediment trap. Although blooms of $P$. pouchetii are often recorded in the Fram Strait (Hop et al. 2006), P. pouchetii does not contribute significantly to carbon export unless deep mixing accelerates the downward export (Reigstad \& Wassmann 2007). Because Phaeocystis spp. cells are typically retained in the upper 50 to $100 \mathrm{~m}$ (Reigstad \& Wassmann 2007), P. pouchetii cells collected at $340 \mathrm{~m}$ were likely exported within the downwelling columns found on either side of a cyclonic eddy (Niebauer \& Smith 1989). In fact, P. pouchetii cells were potentially exported deeper than the sediment trap depth, as the cyclonic motion and warm water influence of eddies were previously observed beyond $600 \mathrm{~m}$ in the eastern Fram Strait (Wadhams \& Squire 1983, Johannessen et al. 1987b). The large $P$. pouchetii export was followed by a period of elevated coccolithophore and $\mathrm{CaCO}_{3}$ fluxes, suggesting that a coccolithophore bloom was taking place at the surface and that the eddy contributed to the rapid export of these small cells. Typically observed in the warmer waters of the northern North Atlantic and the Norwegian Sea, coccolithophore blooms were recently observed further north (Hegseth \& Sundfjord 2008). In their study, Hegseth \& Sundfjord (2008) concluded that the coccolithophore bloom observed in the marginal ice zone of the Barents Sea in August 2003 was due to the subsurface circumpolar boundary current carrying water of Atlantic origin west of Svalbard and then eastwards along the Eurasian Shelf break. The same boundary current explains the presence of a coccolithophore bloom in the Atlantic Water of the eastern Fram Strait in June 2003, which was probably carried to the sediment trap by the ice-edge eddy.

Appendicularian fecal pellet fluxes abruptly dominated the export of fecal pellets at the onset of the iceedge eddy. Appendicularians are soft-bodied zooplankton commonly abundant in the cold waters of sub-Arctic and Arctic seas that often contribute substantially to carbon export through fecal pellets and which were also abundant in the Fram Strait in spring 2003 (Bauerfeind et al. 1997, Vargas et al. 2002, Hopcroft et al. 2005, Blachowiak-Samolyk et al. 2007). The dominance of appendicularian fecal pellets and the near absence of copepod fecal pellets in 
the fecal pellet fluxes during several days suggest a higher grazing pressure from appendicularians. Indeed, these filter-feeders are capable of much higher rates of ingestion, growth, and reproduction than copepods, allowing them to respond more rapidly to shifts in primary productivity (Hopcroft et al. 2005). Thus, it appears that appendicularians were either advected with the Atlantic Water or were better adapted to take advantage of the change in phytoplankton composition associated with the rapid input of Atlantic Water, which contributed to a large export of carbon through appendicularian fecal pellets in June. Another possible explanation for the near absence of copepod fecal pellets in fecal pellet fluxes may be the fragmentation of the copepod fecal pellets due to orbital currents of up to $40 \mathrm{~cm} \mathrm{~s}^{-1}$ associated with the eddy (Johannessen et al. 1987a,b), a possibility supported by the fragmented copepod fecal pellets collected in the sediment trap at the onset of the eddy.

After several days, the almost total contribution of appendicularian fecal pellets to fecal pellet fluxes decreased toward an equal contribution of copepods and appendicularians, and eventually back to a predominance of copepod fecal pellets in the fecal pellet fluxes. This shift in the composition of the fecal pellet fluxes possibly reflects a decrease in the influence of Atlantic Water, with fecal pellet fluxes returning to their pre-eddy proportions after 20 to $24 \mathrm{~d}$. Although ice concentration maps indicate the presence of the eddy until the beginning of July, the material collected in the sediment trap suggests that the eddy signal disappeared earlier at depth. Concurrently with the increasing proportion of copepod fecal pellets, the fecal pellet fluxes and the average size of fecal pellets rapidly decreased at the end of June. While the steady increase in fecal pellet size from May to June probably reflected the increasing size of the zooplankton present in the community, the rapid decrease in the size of zooplankton fecal pellets in June may reflect fragmentation processes above the sediment trap. Indeed, the small pieces of pellets collected in the sediment trap, the steady decrease in fecal pellet fluxes, and the low proportion of fecal pellets in the POC flux suggest that coprophagy, the ingestion of fecal pellets by copepods, and/or coprorhexy, the fragmentation of fecal pellets by copepods, occurred in June (Noji et al. 1991, Turner 2002, Wexels Riser et al. 2002). The fragmentation of fecal pellets through coprophagy and coprorhexy likely contributed to the retention of fecal pellets in the upper water column by lowering their sinking rates (Noji et al. 1991, Turner 2002, Wexels Riser et al.
2002). These processes possibly occurred in response to a decline in food availability at this time, as reflected by the diatom resting spores and empty diatom frustules collected in the sediment trap.

A significant decrease in POC, phytoplankton cell, and fecal pellet fluxes occurred during the last days of the short deployment in July. This decline may reflect the prevalence of a retention food chain due to a more complex zooplankton community, with a higher capacity of recycling in summer compared to spring, which is in accordance with observations previously made in the Barents Sea (Olli et al. 2002). On the other hand, the reduced fecal pellet fluxes in July may reflect the onset of the descent of copepods to depth, as supported by observations of the preparation for the descent of Calanus hyperboreus in July in the Greenland Sea (Hirche 1997), the aggregation of C. hyperboreus over the ocean floor of the Greenland Sea in late July (Hirche et al. 2006), and the accumulation of overwintering stock of Calanus spp. at depth in July in the Barents Sea (Arashkevich et al. 2002). However, it is more likely that the low export fluxes observed in July reflect the retention capacity of the higher zooplankton abundance and biomass observed later in the season in the eastern Fram Strait (Blachowiak-Samolyk et al. 2007).

\section{CONCLUSIONS}

The deployment of a sediment trap at a high temporal resolution allowed us to better assess the development of the phytoplankton and zooplankton communities and their influence on the magnitude and composition of the downward POC export in the eastern Fram Strait. Although high POC export was associated with the sinking of the diatom bloom at the beginning of May, most of the POC export was associated with the advection of Atlantic Water in the sampling region due to an ice-edge eddy. The input of Atlantic Water affected the composition of the exported phytoplankton cells and zooplankton fecal pellets, underscoring the importance of water masses in shaping POC export in the eastern Fram Strait. A similar influence of water masses was observed in the Barents Sea, where the composition of the sinking particles was different in Arctic and Atlantic waters (Olli et al. 2002) and where the main contributors to the fecal pellet flux varied depending on the prevailing water masses and phytoplankton bloom stage (Wexels Riser et al. 2008). Although water masses strongly influence export fluxes, ice cover also affects POC export in the eastern Fram Strait, 
mainly through the release of particles during ice melt (Bauerfeind et al. 2009). Nonetheless, our results suggest that the recent increases in the volume and temperature of the Atlantic Water flowing into the Arctic Ocean through the Fram Strait (Walczowski \& Piechura 2006) likely affected the composition of the POC flux, and that potential 'atlantification' of the Fram Strait could significantly influence POC export in this region.

Furthermore, the immediate shift in the composition of the export fluxes during the formation of the ice-edge eddy suggests that such events lead to rapid POC export. Smith et al. (1987) concluded that, since approximately 10 to $20 \%$ of the marginal ice zone of the Fram Strait is impacted by cyclonic eddies, these features may introduce large spatial and temporal variability into biological processes and may have significant impact on the entire food web of the region. This hypothesis was confirmed by our results, which clearly showed that eddies are important for the downward export of small phytoplankton cells, further implying that their effect should be considered in the estimation of annual POC export.

Acknowledgements. We thank the crew of the RV 'Polarstern' and the late J. Wegner for the deployment and recovery of the sediment trap. We thank L. Kaleschke for providing sea ice concentration data and C. Lorenzen for laboratory work. This study was funded by the HGF MPG Joint Research Group on Deep Sea Ecology and Technology. C.L. received financial support from the Alexander von Humboldt Foundation.

\section{LITERATURE CITED}

Andreassen I, Nöthig EM, Wassmann P (1996) Vertical particle flux on the shelf off northern Spitsbergen, Norway. Mar Ecol Prog Ser 137:215-228

> Arashkevich E, Wassmann P, Pasternak A, Wexels Riser C (2002) Seasonal and spatial changes in biomass, structure, and development progress of the zooplankton community in the Barents Sea. J Mar Syst 38:125-145

Bauerfeind E, Garrity C, Krumbholz M, Ramseier RO, Vo M (1997) Seasonal variability of sediment trap collections in the Northeast Water Polynya. Part 2. Biochemical and microscopic composition of sedimenting matter. J Mar Syst 10:371-389

Bauerfeind E, Nöthig EM, Beszczynska A, Fahl K and others (2009) Particle sedimentation patterns in the eastern Fram Strait during 2000-2005: results from the Arctic long-term observatory HAUSGARTEN. Deep-Sea Res I 56:1471-1487

Bélanger S, Babin M, Larouche P (2008) An empirical ocean color algorithm for estimating the contribution of chromophoric dissolved organic matter to total light absorption in optically complex waters. J Geophys Res 113: C04027. doi:10.1029/2007JC004436

Blachowiak-Samolyk K, Kwasniewski S, Dmoch K, Hop H,
Falk-Petersen S (2007) Trophic structure of zooplankton in the Fram Strait in spring and autumn 2003. Deep-Sea Res II 54:2716-2728

> Dagg MJ, Urban-Rich J, Peterson JO (2003) The potential contribution of fecal pellets from large copepods to the flux of biogenic silica and particulate organic carbon in the Antarctic Polar Front region near $170^{\circ} \mathrm{W}$. Deep-Sea Res II 50:675-691

> Fortier M, Fortier L, Michel C, Legendre L (2002) Climatic and biological forcing of the vertical flux of biogenic particles under seasonal Arctic sea ice. Mar Ecol Prog Ser 225:1-16

Garver DL, Siegel DA (1997) Inherent optical property inversion of ocean color spectra and its biogeochemical interpretation. 1. Time series from the Sargasso Sea. J Geophys Res 102(C108):18607-18625

González HE, Smetacek V (1994) The possible role of the cyclopoid copepod Oithona similis in retarding the vertical flux of zooplankton faecal material. Mar Ecol Prog Ser 113:233-246

González HE, Gonzalez SR, Brummer GJA (1994) Shortterm sedimentation pattern of zooplankton, faeces and microplankton at a permanent station in the Bjornafjorden (Norway) during April-May 1992. Mar Ecol Prog Ser 105:31-45

Graf G (1989) Benthic-pelagic coupling in a deep-sea benthic community. Nature 341:437-439

> Grebmeier JM, Barry JP (1991) The influence of oceanographic processes on pelagic-benthic coupling in polar regions: a benthic perspective. J Mar Syst 2:495-518

Hebbeln D (2000) Flux of ice-rafted detritus from sea ice in the Fram Strait. Deep-Sea Res II 47:1773-1790

> Hegseth EN, Sundfjord A (2008) Intrusion and blooming of Atlantic phytoplankton species in the high Arctic. J Mar Syst 74:108-119

- Hirche HJ (1997) Life cycle of the copepod Calanus hyperboreus in the Greenland Sea. Mar Biol 128:607-618

> Hirche HJ, Muyakshin S, Klages M, Auel H (2006) Aggregation of the Arctic copepod Calanus hyperboreus over the ocean floor of the Greenland Sea. Deep-Sea Res I 53: 310-320

> Hop H, Falk-Petersen S, Svendsen H, Kwasniewski S, Pavlov V, Pavlova O, Søreide JE (2006) Physical and biological characteristics of the pelagic system across Fram Strait to Kongsfjorden. Prog Oceanogr 71:182-231

Hopcroft RR, Clarke C, Nelson RJ, Raskoff KA (2005) Zooplankton communities of the Arctic's Canada Basin: the contribution by smaller taxa. Polar Biol 28:198-206

Johannessen JA, Johannessen OM, Svendsen E, Shuchman $\mathrm{R}$ and others (1987a) Mesoscale eddies in the Fram Strait marginal ice zone during the 1983 and 1984 marginal ice zone experiments. J Geophys Res 92:6754-6772

> Johannessen OM, Johannessen JA, Svendsen E, Shuchman RA, Campbell WJ, Josberger E (1987b) Ice-edge eddies in the Fram Strait marginal ice zone. Science 236:427-429

Klages M, Boetius A, Christensen JP, Deubel H, Piepenburg D, Schewe I, Soltwedel T (2004) The benthos of Arctic Seas and its role for the organic carbon cycle at the seafloor. In: Stein R, Macdonald RW (eds) The organic carbon cycle in the Arctic Ocean. Springer, New York, NY, p 139-168

Kremling K, Lentz U, Zeitzschel B, Schulz-Bull DE, Duinker JC (1996) New type of time-series sediment trap for the reliable collection of inorganic and organic trace chemical substances. Rev Sci Instrum 67:4360-4364 
Lalande C, Grebmeier JM, Wassmann P, Cooper LW, Flint MV, Sergeeva VM (2007) Export fluxes of biogenic matter in the presence and absence of seasonal sea ice cover in the Chukchi Sea. Cont Shelf Res 27:2051-2065

$>$ Maritorena S, Siegel DA (2005) Consistent merging of satellite ocean color data sets using a bio-optical model. Remote Sens Environ 94:429-440

Maritorena S, Siegel DA, Peterson AR (2002) Optimization of a semianalytical ocean color model for global-scale applications. Appl Opt 41:2705-2714

Niebauer HJ, Smith WOJ (1989) A numerical model of mesoscale physical-biological interactions in the Fram Strait marginal ice zone. J Geophys Res 94:16151-16175

Noji TT, Estep KW, MacIntyre F, Norrbin F (1991) Image analysis of faecal material grazed upon by three species of copepods: evidence for coprorhexy, coprophagy and coprochaly. J Mar Biol Assoc UK 71:465-480

Olli K, Riser CW, Wassmann P, Ratkova T, Arashkevich E, Pasternak A (2002) Seasonal variation in vertical flux of biogenic matter in the marginal ice zone and the central Barents Sea. J Mar Syst 38:189-204

Peinert R, Bauerfeind E, Gradinger R, Haupt O, Krumbholz M, Peeken I, Werner I, Zeitzschel B (2001) Biogenic particle sources and vertical flux patterns in the seasonally ice-covered Greenland Sea. The northern North Atlantic: a changing environment. Springer, New York, NY

Polyakov IV, Beszczynska A, Carmack EC, Dmitrenko IA and others (2005) One more step toward a warmer Arctic. Geophys Res Lett 32:L17605. doi:10.1029/2005GL023740

Reigstad M, Wassmann P (2007) Does Phaeocystis spp. contribute significantly to vertical export of organic carbon? Biogeochemistry 83:217-234

Sakshaug E (2004) Primary and secondary production in the Arctic Seas. In: Stein R, Macdonald RW (eds) The organic carbon cycle in the Arctic Ocean. Springer, New York, NY, p $57-82$

Sampei M, Forest A, Sasaki H, Hattori H, Makabe R, Fukuchi M, Fortier L (2009) Attenuation of the vertical flux of copepod fecal pellets under Arctic sea ice: evidence for an active detrital food web in winter. Polar Biol 32:225-232

Schauer U, Fahrbach E, Osterhus S, Rohardt G (2004) Arctic warming through the Fram Strait: oceanic heat transport from 3 years of measurements. J Geophys Res 109:C06026. doi: 10.1029/2003JC001823

Shuchman RA, Burns BA, Johannessen OM, Josberger EG, Campbell WJ, Manley TO, Lannelongue N (1987) Remote sensing of the Fram Strait marginal ice zone. Science 236:429-431

Smith W Jr, Baumann M, Wilson D, Aletsee L (1987) Phytoplankton biomass and productivity in the marginal ice zone of the Fram Strait during summer 1984. J Geophys

Editorial responsibility: Marsh Youngbluth,

Fort Pierce, Florida, USA
Res 92:6777-6786

Soltwedel T, Jaeckisch N, Ritter N, Hasemann C, Bergmann M, Klages M (2009) Bathymetric patterns of megafaunal assemblages from the arctic deep-sea observatory HAUSGARTEN. Deep-Sea Res I 56:1856-1872

Spreen G, Kaleschke L, Heygster G (2008) Sea ice remote sensing using AMSR-E 89-GHz channels. J Geophys Res 113:C02S03. doi: 10.1029/2005JC003384

Turner JT (2002) Zooplankton fecal pellets, marine snow and sinking phytoplankton blooms. Aquat Microb Ecol 27: 57-102

Utermöhl H (1958) Zur Vervollkommnung der quantitativen Phytoplankton-Methodik. Mitt Int Verh Limnol 9:1-38

- Vargas CA, Tönnesson K, Sell A, Maar M and others (2002) Importance of copepods versus appendicularians in vertical carbon fluxes in a Swedish fjord. Mar Ecol Prog Ser 241:125-138

von Bodungen B, Wunsch M, Fürderer H (1991) Sampling and analysis of suspended and sinking particles in the northern North Atlantic. In: Hurt DC, Spencer DW (eds) Marine particles: analysis and characterization. Book Geophysical Monograph Ser. Vol 63. American Geophysical Union, Washington, DC, p 47-53

von Quillfeldt CH (2000) Common diatom species in Arctic spring blooms: their distribution and abundance. Bot Mar 43:499-516

Wadhams P, Squire V (1983) An ice-water vortex at the edge of the East Greenland Current. J Geophys Res 88: 2770-2780

> Walczowski W, Piechura J (2006) New evidence of warming propagating toward the Arctic Ocean. Geophys Res Lett 33:L12601. doi:10.1029/2006GL025872

Wassmann P, Bauerfeind E, Fortier M, Fukuchi M and others (2004) Particulate organic carbon flux to the Arctic Ocean sea floor. In: Stein R, Macdonald RW (eds) The organic carbon cycle in the Arctic Ocean. Springer, New York, NY, p 101-138

Wassmann P, Andreassen I, Reigstad M, Slagstad D (1996) Pelagic-benthic coupling in the Nordic Seas: the role of episodic events. PSZNI Mar Ecol 17:447-471

> Wexels Riser C, Wassmann P, Olli K, Pasternak A, Arashkevich $E$ (2002) Seasonal variation in production, retention and export of zooplankton faecal pellets in the marginal ice zone and central Barents Sea. J Mar Syst 38:175-188

> Wexels Riser C, Wassmann P, Reigstad M, Seuthe L (2008) Vertical flux regulation by zooplankton in the northern Barents Sea during Arctic spring. Deep-Sea Res II 55: 2320-2329

Wu Y, Peterson IK, Tang CCL, Platt T, Sathyendranath S, Fuentes-Yaco C (2007) The impact of sea ice on the initiation of the spring bloom on the Newfoundland and Labrador shelves. J Plankton Res 29:509-514

Submitted: April 5, 2011; Accepted: September 5, 2011 Proofs received from author(s): October 20, 2011 